\title{
Peranan Leverage dan Profitabilitas Terhadap Sustainable Growth: Studi pada Sektor Manufaktur di BEI
}

\author{
Arinta Chandradinangga ${ }^{1}{ }^{*}$, Maria Rio Rita ${ }^{2}$ \\ 1,2Program Studi Manajemen, Fakultas Ekonomika dan Bisnis, Universitas Kristen Satya Wacana
}

\section{A R T I C L E I N F O}

\section{Article history:}

Received 15 February 2020

Received in revised form

30 March 2020

Accepted 20 April 2020

Available online 28 May 2020

\section{Kata Kunci:}

Sustainable growth

leverage, profitabilitas

Keywords:

Sustainable Growth,

Leverage, Profitability

\begin{abstract}
A B S T R A K
Kajian mengenai keberlanjutan (sustainability) cukup menarik minat beberapa peneliti akhir-akhir ini, baik pada level usaha kecil maupun korporat. Sustainable growth menjadi salah satu tolak ukur kinerja perusahaan yang baik karena mengkombinasikan antara kebijakan operasi dan kebijakan keuangan. Hutang yang tinggi bagi perusahaan tidak selamanya buruk namun perlu adanya pengawasan dan perencanaan sehingga dapat menjadikan sebuah strategi bisnis perusahaan. Penelitian ini bertujuan untuk menganalisis pengaruh leverage dan profitabilitas terhadap sustainable growth pada perusahaan sektor manufaktur pada tahun 2015-2017 yang terdaftar dalam Bursa Efek Indonesia (BEI). Pemilihan sampel pada penelitian ini menggunakan metode purposive sampling dan diperoleh sebanyak 70 perusahaan sesuai dengan kriteria yang ada. Penelitian ini menggunakan analisis regresi linear berganda untuk menganalisis datanya. Berdasarkan pengujian hipotesis dapat dinyatakan bahwa leverage berpengaruh positif signifikan terhadap sustainable growth, sedangkan profitabilitas berpengaruh positif signifikan terhadap sustainable growth.
\end{abstract}

A B S T R A C T

The study of sustainability has attracted the interest of some researchers lately, both at the level of small businesses and corporate. Sustainable growth is one measure of good company performance because it combines operating and financial policies. Companies that have high debts are not always bad, but they need supervision and planning so as to produce optimal decisions for the company. This study aims to analyse the effect of leverage and profitability on sustainable growth in manufacturing sector companies in 2015-2017 which are listed on the Indonesia Stock Exchange (IDX). The purposive sampling approach was used in the selection of samples, and obtained as many as 70 companies in accordance with existing criteria. This study uses multiple linear regression analysis to process the data. This study proves that leverage has a significant positive effect on sustainable growth, while profitability has a significant positive effect on sustainable growth.

\footnotetext{
* Corresponding author.

E-mail addresses: chandraari@gmail.com (Arinta Chandradinangga)
} 


\section{Pendahuluan}

Pengelolaan sumber keuangan perusahaan tidak terlepas dari peran manajer keuangannya, dengan memperhatikan dampak yang timbul akibat keputusan sumber pendanaan yang diambil. Sumber pendanaan dibagi menjadi dua, yaitu pendanaan dari dalam dan pendanaan dari luar perusahaan (Brealey et al., 2011). Saldo laba menjadi alternatif dari sumber pendanaan internal. Penerbitan saham, penerbitan obligasi, dan pinjaman dari bank merupakan sumber pendanaan luar perusahaan. Menurut Arsov \& Naumoski, (2016) mengatakan bahwa profitabilitas yang semakin tinggi maka akan menurukan penggunaan hutang sebagai pendanaan perusahaan. Pendanaan internal dipengaruhi oleh profitabilitas yang didapatkan perusahaan. Apabila profitabilitas perusahaan menurun maka perusahaan memerlukan pendanaan ekternal yang dapat berasal dari pinjaman bank, namun perlu memperhatikan dampak yang akan ditimbulkan akibat menggunakan dana yang berasal dari hutang, salah satu dampak yang muncul oleh hutang adalah kebangkrutan bagi bisnis perusahaan (Kristanto, 2012).

Mempertahankan perusahaan bukanlah hal yang mudah, kondisi ini tercermin dari kejadiaan sepanjang tahun 2017 terdapat delapan (8) perusahaan bangkrut yang diakibatkan olehkrtidak mampuan dalam membayar kreditur (Sari, 2017) dan pada tahun 2018 terdapat perusahaan besar produsen teh yang dinyatakan pailit oleh pengadilan dikarenakan gagal dalam pembayaran hutangnya (Setipu, 2018). Sembilan perusahaan ini dinyatakan pailit karena hutangnya yang tinggi sehingga tidak dapat terbayarkan. Menurut Kristanto, (2012) pinjaman tinggi mengakibatkan kebangkrutan perusahaan. Hutang yang besar berdampak pada munculnya biaya bunga yang besar, sehingga memungkinkan perusahaan mengalami gagal bayar. Keadaan ini berbeda dengan keadaan perusahaan manufaktur pada tahun 2017 terdaftar dalam Bursa Efek Indonesia (BEI). Terdapat 17 perusahaan dengan kode (INAI, INCF, SCPI, UNVR, RICY, KDSI, VOKS, PICO, WTON, BUDI, AKPI, KAEF, MLBI, ALDO, NIPS, SKLT, dan MYOR) perusahaan dengan memiliki hutang tinggi namun perusahaan tersebut terus berjalan. Hutang yang tinggi ini diartikan dari perbandingan antara total hutang perusahaan dan total ekuitas perusahaan. Bahkan 17 perusahaan tersebut mendanai modalnya dengan hutang sepenuhnya, namun 17 perusahaan tersebut memiliki nilai sustainable growth yang positif. Sustainable growth dapat menjadi sebuah tolak ukur yang baik untuk perusahaan karena mengkombinasikan antara kebijakan operasi dengan kebijakan keuangan (Amouzesh et al. 2011). Sustainable growth itu sendiri merupakan tingkat pertumbuhan penjualan maksimal perusahaan tanpa merubah kebijakan pendanaannya (Higgins, 1981).

Keadaan ini tidak dapat lepas dari peran seorang manajer keuangan. Seorang manajer harus mampu mencapai tujuan dari perusahaan yang telah direncanakan sebelumnya. Perusahaan untuk mampu mencapai tujuan itu harus mampu mengkombinasikan sumber daya yang tersedia, sehingga mendapatkan hasil dan laba yang dihasilkan oleh perusahaan secara optimal. Perusahaan yang menginginkan kelangsungan hidup dapat dipengaruhi oleh beberapa faktor salah satunya adalah profiabilitas perusahaan (Barus \& Leliani, 2013). Baik buruknya sebuah perusahaan dapat dinilai dengan profitabilitas. Profitabilitas itu sendiri merupakan efektivitas perusahaan dalam memanfaatkan penggunaan aktivanya untuk mendapatkan keuntungan.

Penelitian terdahulu telah dilakukan oleh Nasim \& Irnama, (2015), Destikasai \& Tandika, (2019) telah menghubungkan antara pengaruh leverage terhadap sustainable growth, yang keduanya menghasilkan hubungan positif. Penelitan yang telah dilakukan oleh Rahim, (2017) telah menganalisis hubungan antara financial leverage, liquidity, dan assets efficiency terhadap sustainable growth, namun hanya menghasilkan hubungan yang kecil dan memperlukan variable lain seperti profitabilitas. Menurut penelitan Amouzesh et al., (2011) menghasilkan temuan bahwa profitabilitas memiliki hubungan dengan sustainable growth. Sejalan dengan penelitan sebelumnya bahwa Mukherjee \& Sen, (2018) menghasilkan temuan bahwa profitabilitas memiliki pengaruh positif dengan sustainable growth. Namun sejauh ini masih minim penelitian yang menggabungkan leverage, profitabilitas dan sustainable growth dalam satu penelitian. Dengan demikian, riset ini mengkolaborasikan pengaruh antara leverage dan profitabilitas terhadap sustainable growth, sehingga temuan ini bisa memberikan perspektif beragam mengenai kajian keberlanjutan usaha khususnya bagi perusahaan korporat.

\section{Metode}

Populasi pada penelitian ini merupakan perusahaan pada sektor manufaktur yang terdaftar di Bursa Efek Indonesia (BEI) dari tahun 2015-2017. Argumen peneliti menggunakan perusahaan manufaktur dikarenakan perusahaan inilah yang paling banyak sehingga dapat merepresentasikan keadaan perusahaan-perusahaan lain yang di BEI. Metode untuk pengambilan sampel pada penelitian ini dengan cara purposive sampling. Berikut tabel pemilihan sampel: 
Tabel 1. Pemilihan Sampel

\begin{tabular}{clc}
\hline No & \multicolumn{1}{c}{ Kriteria } & Jumlah Perusahaan \\
\hline 1. & Total perusahaan manufaktur yang terdaftar di BEI pada tahun & 141 \\
& $2015-2017$ & \\
2. & Perusahaan yang tidak memiliki kelengkapan data selama & $(2)$ \\
& periode tahun 2015-2017 & \\
3. & Menggunakan mata uang selain rupiah & $(10)$ \\
4. & Perusahaan yang merugi pada periode tahun 2015-2017 & $(59)$ \\
\hline Jumlah sampel akhir & $\mathbf{7 0}$ \\
Tahun pengamatan & $\mathbf{3}$ \\
Jumlah pengamatan & $\mathbf{2 1 0}$ \\
\hline
\end{tabular}

Menurut Dino, (2016), konsep pertumbuhan mensyaratkan sebuah perusahaan harus dalam keadaan tidak merugi, sehingga akan menghasilkan nilai sustainable growth positif. Jenis data dalam studi ini adalah data panel, yaitu gabungan dari data cross section dan time series. Sumber data yang diinginkan merupakan data sekunder, dengan cara mengakses website Bursa Efek Indonesia (www.idx.co.id) dan website resmi perusahaan terkait.

Untuk mengetahui pengukuran variabel pada leverage, profitabilitas, dan sustainable growth menggunakan rasio sebagai berikut.

Tabel 2. Pengukuran Variabel

\begin{tabular}{lccc}
\hline \multicolumn{1}{c}{ Variabel } & Indikator & Skala & Sumber \\
\hline $\begin{array}{l}\text { Leverage } \\
\text { (DER) }\end{array}$ & $\begin{array}{l}\text { Total Hutang } \\
\text { Total Equity }\end{array}$ & Rasio & Fonseka et al. (2012) \\
$\begin{array}{l}\text { Profitabilitas } \\
\text { (ROA) }\end{array}$ & $\begin{array}{l}\text { Laba Bersih } \\
\frac{\text { Total Aset }}{\text { Sustainable Growth }}\end{array}$ & Rasio & Hongli et al. (2019) \\
(SGR) & $\begin{array}{c}\text { Retention rate x ROE } \\
\text { (1-DPR) x ROE }\end{array}$ & Rasio & Higgins (1977) \\
\hline
\end{tabular}

Teknik analisis pada penelitian ini menggunakan teknik analisis regresi linear berganda dengan melalui model Ordinary Least Square (OLS). Pengolahan analisis ini menggunakan aplikasi SPSS 26. Uji asumsi klasik untuk memastikan model yang digunakan terbebas dari masalah normalitas, multikolinearitas, heteroskedastisitas, dan autokorelasi juga dilakukan. Kemudian melakukan uji hipotesis. Bentuk model regresi linear berganda penelitian ini sebagai berikut:

$Y=\alpha+\beta \_1 X \_1+\beta \_2 X \_2+\varepsilon$

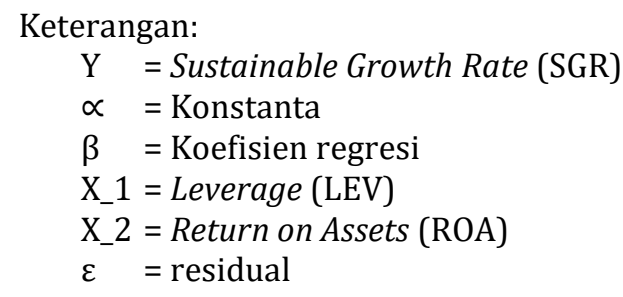

\section{Hasil dan Pembahasan}

\section{A. Statistik Deskriptif}

Tabel 2 akan memberikan profil data penelitian dengan menyajikan pada rata-rata, standar deviasi, nilai minimum dan nilai maksimum. Studi ini menggunakan 70 perusahaan pada sector manufaktur yang terdaftar di BEI selama periode 2015-2017. Data variabel dependen dan variabel independen diperoleh dari website Bursa Efek Indonesia dan website resmi perusahaan terkait. 
Tabel 3. Statistik Deskriptif

\begin{tabular}{ccccc}
\hline Variables & Mean & $\begin{array}{c}\text { Standard } \\
\text { Deviasi }\end{array}$ & Minimum & Maximum \\
\hline SGR (\%) & 9,07 & 14,90 & $-16,30$ & 142,42 \\
LEV (x) & 93 & 1,19 & 0,08 & 13,98 \\
ROA (\%) & 8,76 & 8,56 & 0,02 & 52,67 \\
\hline
\end{tabular}

Rata-rata sustainable growth perusahaan sector manufaktur di Indonesia sebesar 9,07 persen. Walaupun perusahaan manufaktur di Indonesia mampu untuk bertumbuh dan berkelanjutan namun masih kecil pendanaan internalnya untuk mendukung sustainable growth. Sementara itu masih tinggi hutang yang digunakan oleh perusahaan manufaktur Indonesia dalam membiayai kegiatan operasi perusahaan. Sebesar 93 persen nilai pada leveragenya, yang artinya rata-rata perusahaan manufaktur di Indonesia lebih dari setengah modalnya dibiayai oleh hutang. Hutang yang tinggi banyak diberlakukan pada perusahaan sub sektor makanan dan minuman. Di sisi lain, kemampuan perusahaan manufaktur di Indonesia dalam kemampuannya menghasilkan laba hanya sebesar 8,76 persen dan relatif bervariasi, apabila dipriksa dari standar deviasi, rata-rata, nilai minimum, dan nilai maksimumnya.

\section{B. Uji Asumsi Klasik}

Uji asumsi klasik yang bertujuan untuk memastikan model regresi telah memenuhi kriteria BLUE (Best, Linear, Unbiased Estimator). Berikut uji asumsi klasik yang dilakukan dalam penelitian ini sebagai berikut:

\section{Uji Normalitas}

Uji Normalitas, dalam pengujian ini untuk mengetahui apakah uji residual berdistribusi normal atau tidak. Pengujian normalitas ini menggunakan uji Kolmogorov-Smirnov. Uji ini bisa terpenuhi apabila nilai residual lebih besar dari nilai signifikansi. Nilai signifikansi yang diberlakukan dalam penelitian ini sebesar 0,05. Tabel dibawah ini menunjukan hasil uji normalitas.

Tabel 4. Hasil Uji Normalitas Kolmogorov-Smirnov

\begin{tabular}{ccc}
\hline Variabel & Probability Value & Asumsi Normalitas \\
\hline Unstandardized Residual & 0,200 & Terpenuhi \\
\hline & & Sumber: Data Sekunder yang Diolah (2020)
\end{tabular}

\section{Uji Multikoleniaritas}

Uji Multikoleniaritas, pengujian ini bertujuan untuk mengetahui korelasi antara variable bebas. Penggunaan pengujian ini dengan membandingkan nilai tolerance dan nilai VIF. Pengujian ini lolos apabilai nilai tolerance harus lebih besar dari 0,10 dan pada nilai VIF kurang dari 10. Berikut merupakan tabel hasil uji multikoleniaitas masing-masing variabel.

Tabel 5. Hasil Uji Multikolinearitas

\begin{tabular}{cccc}
\hline Variabel & Tolerance & VIF & Asumsi Multikolinearitas \\
\hline LEV & 0,782 & 1,279 & Tidak terjadi multikolinearitas \\
ROA & 0,782 & 1,279 & Tidak terjadi multikolinearitas \\
\hline & & Sumber: Data Sekunder yang Diolah (2020)
\end{tabular}

\section{E. Uji Heteroskedastisitas}

Uji Heteroskedastisitas, dalam pengujian ketiga ini untuk melihat apakah terjadi ketidakcocokan variabel dalam suatu model yang dianalisis dengan menggunakan uji glesjer. Pengujian ini membandingkan antara signifikansi probability value dengan signifikansi 0,05 . Pengujian ini dikatakan lolos apabilah nilai dari signifikansi probability value harus lebih besar dari pada signifikansi 0,05. 
Tabel 6. Hasil Uji Heteroskedastisitas

\begin{tabular}{ccc}
\hline Variabel & Probability Value & Asumsi Heteroskedastisitas \\
\hline LEV & 0,129 & Tidak terjadi Heteroskedastisitas \\
ROA & 0,679 & Tidak terjadi Heteroskedastisitas \\
\hline & & Sumber: Data Sekunder yang Diolah $(2020)$
\end{tabular}

\section{F. Uji Autokorelasi}

Uji Autokorelasi, uji ini bertujuan untuk memperlihatkan apakah ada tidaknya korelasi antara masa lalu dengan masa sekarang, dengan menggunakan uji Durbin-Watson. Nilai DW sebesar 2,026. Dengan jumlah data $(\mathrm{n})=168$ dan variable bebas $(\mathrm{k})=2$, $\mathrm{du}=1,7718 \mathrm{dl}=1,7236$ berada pada batas $(\mathrm{du})$ dan (4-du), maka tidak terjadi autokorelasi.

\section{G. Analisis Regresi Linear Berganda}

Model regresi pada studi ini dipergunakan untuk memperlihatkan bagaimana pengaruh leverage (X1), dan profitabilitas (X2) terhadap sustainable growth (Y) perusahaan manufaktur yang terdaftar dalam BEI.

Tabel 7. Hasil Uji Regresi Linear Berganda

\begin{tabular}{cccc}
\hline \multirow{2}{*}{ Model } & \multicolumn{2}{c}{$\begin{array}{c}\text { Unstandardized } \\
\text { Coefficients }\end{array}$} & \multirow{2}{*}{ Sig } \\
\cline { 2 - 3 } & B & Std. Error & \\
\hline (Constant) & 0,462 & 0,057 & 0,000 \\
X1_LEV & 0,465 & 0,050 & 0,000 \\
X2_ROA & 0,961 & 0,032 & 0,000 \\
\hline
\end{tabular}

Adjusted $R$ Square $=0,845 \quad \mathrm{~F}=456,209 ;$ Sig $=0,000$

Sumber: Data Sekunder yang Diolah (2020)

Dari tabel 6 di atas, memperoleh model persamaan regresi linear berganda sebagai berikut. Persamaan regresi:

$\mathrm{Y}=0,462+0,465 \mathrm{X} 1+0,961 \mathrm{X} 2+\varepsilon$

Nilai adjusted R2 yaitu 0,845 atau $84,5 \%$ variabel leverage dan profitabilitas memengaruhi sustainable growth, sedangkan $15,5 \%$ dipengaruhi oleh variabel lain yang tidak masuk dalam pengamatan. Uji f yang diperoleh dari uji ANOVA sebesar 456,209 yang lebih besar dari pada $\mathrm{f}$ tabel $(456,209>3,05)$, yang berarti $\mathrm{H} 0$ ditolak dan Ha diterima. Berdasarkan hasil tersebut, sehingga leverage dan profitabilitas berpengaruh terhadap sustainable growth. Uji t dilakukan untuk melihat leverage dan profitabilitas secara parsial berpengaruh terhadap sustainable growth.

Hasil statistik uji t pada penelitian ini bahwa nilai pada leverage (H1) terhadap sustainable growth lebih besar dari pada $t$ tabel $(9,245>1,974)$ dan nilai signifikasi lebih kecil dari pada $\alpha(0,000<0,05)$. Penelitian ini menghasilkan nilai koefisien regresi beta pada variabel leverage bernilai positif sebesar 0,465. Sehingga dalam studi ini hipotesis (H1) diterima dengan menyatakan bahwa leverage berpengaruh positif signifikan terhadap sustainable growth. Keadaan ini terjadi karena pendanaan yang berasal dari luar perusahaan membantu perusahaan untuk menambah modal perusahaan dalam oprasionalnya, sehingga dapat meningkatkan output penjualannya yang akan berdampak pada peningkatan sustainable growth. Penelitian ini sejalan dengan penelitian yang telah dilakukan oleh Rahim, (2017), Mukherjee \& Sen, (2018), dan Destikasai \& Tandika, (2019). Apabila dana yang berasal dari internal perusahaan tidak mencukupi untuk membiayai oprasional perusahaan sehingga perusahaan memperlukan pendanaan yang berasal dari luar. Menurut Kristen et al., (2015) jika modal tidak datang dari penyedia kredit maka akan menghambat laju pertumbuhan dan menurunkan potensi output perusahaan.

Hasil statistik uji t pada penelitian ini diketahui nilai profitabilitas (H2) terhadap sustainable growth lebih besar dari pada $t$ tabel $(30,162>1,974)$ dan nilai signifikasi lebih kecil dari pada $\alpha(0,000<$ $0,05)$. Nilai koefisien regresi beta pada variabel profitabilitas bernilai positif sebesar 0,961 . Sehingga pada penelitian ini hipotesis (H2) diterima dengan menyatakan bahwa profitabilitas berpengaruh positif signifikan terhadap sustainable growth. Keadaan ini terjadi karena konsep sustainable growth mengharapkan sebuah perusahaan mampu memaksimalkan sumber dana yang berasal dari dalam 
perusahaan sehingga laba bersih yang dihasilkan tidak perlu terlalu banyak membayarkan biaya hutang apabila perusahaan sedikit menggunakan pendanaan eksternal, sehingga dapat meningkatkan sustainable growth. Penelitian ini searah dengan penelitian yang dilakukan oleh Rahim, (2017), Mukherjee \& Sen, (2018) dan Amouzesh et al., (2011). Kemampuan perusahaan dalam menghasilkan laba atau profitabilitas maka akan meningkatkan pendanaan internal perusahaan sehingga dapat meningkatkan sustainable growth perusahaan (Nastiti et al., 2019).

\section{Simpulan dan Saran}

Dari pengujian secara statistik yang sudah dilakukan, dapat diambil kesimpulan bahwa variabel leverage berpengaruh positif signifikan terhadap sustainable growth. Semakin tinggi tingkat leverage maka akan meningkatkan sustainable growth. Pendanaan yang bersumber dari hutang dapat menjadikan modal tambahan bagi perusahaan sehingga dapat meningkatkan sustainable growth (Rahim, 2017). Namun tingginya leverage dapat meningkatkan risiko perusahaan gagal bayar sehingga memungkinkan sebuah perusahaan untuk bangkrut (Kristanto, 2012). Dengan demikian, perusahaan perlu untuk terus memantau dan merencanakan tingkat leverage sebagai salah satu strategi bisnis sehingga perusahaan mampu untuk sustainable growth.

Kesimpulan berikutnya adalah, profitabilitas terbukti berpengaruh positif signifikan terhadap sustainable growth. Kemampuan perusahaan dalam mendapatkan laba akan meningkatkan dana internalnya sehingga dapat meningkatkan sustainable growth (Nastiti et al., 2019). Dengan tersedianya dana internal perusahaan maka akan menekan pendanaan dari luar perusahaan yang dapat mengurangi risiko kebangkrutan perusahaan itu sendiri.

Selain itu penelitian yang akan dating dapat menambahkan faktor-faktor lain yang diduga mempengaruhi sustainable growth seperti kebijakan dividen dan manajemen laba (Rahim, 2017). Selain itu, dapat pula menambahkan kebijakan dividen sebagai variabel moderasi terhadap sustainable growth, karena kebijakan dividen memerankan peran penting dalam sustainable growth (Sutjiati 2017).

\section{Daftar Rujukan}

Amouzesh, N., Moenifar, Z., \& Mousavi, Z. (2011). Sustainable Growth Rate and Firm Performance: Evidence From Iran Stock Exchange. International Journal of Business and Social Science, 2(23), 249-255.

Arsov, S., \& Naumoski, A. (2016). Determinants of capital structure: An empirical study of companies from selected post-transition economies. Journal of Economics and Business, 34(1), 119-146. https://doi.org/10.18045/zbefri.2016.1.119

Barus, A. C., \& Leliani. (2013). Analisis Faktor-Faktor Yang Mempengaruhi Profitabilitas Pada Perusahaan Manufaktur Yang Terdaftar Di Bursa Efek Indonesia. Jurnal Wira Ekonomi Mikroskil, 3(02), 111121.

Brealey, R. A., Myers, S. C., \& Allen, F. (2011). Principles of Corporate Finance (10th editi). McGraw-Hill International Edition.

Destikasai, A., \& Tandika, D. (2019). Pengaruh Leverage dan Profit Margin terhadap Sustainable Growth Rate pada Sub Sektor Konstruksi Bangunan yang Terdaftar di Bursa Efek Indonesia Tahun 20142017. Proceedings of Management, 5(1).

Dino, N. V. G. (2016). Pengaruh Cash Adequacy, Intellectual Capital dan Financial Non Distress terhadap Sustainable Growth Rate (Studi pada Perusahaan Manufaktur yang Terdaftar di Bursa Efek Indonesia pada Tahun 2012-2014) [Universitas Jember]. https://doi.org/10.5151/cidi2017-060

Fonseka, M. M., Ramos, C. G., \& Tian, G. L. (2012). The Most Appropriate Sustainable Growth Rate Model For Managers And Researchers. The Journal of Applied Business Research, 28(3), 481-500.

Higgins, R. C. (1977). Much Growth Can Firm Afford? Jornal Financial Management, 6(3), 7-16.

Higgins, R. C. (1981). Sustainable Growth Under Inflation. Journal Financial Management, 10(4), 36-40. 
Hongli, J., Ajorsu, E. S., \& Bakpa, E. K. (2019). The Effect of Liquidity and Financial Leverage on Firm Performance : Evidence from Listed Manufacturing Firms on The Ghana Stock Exchange. Research Journal of Finance and Accounting, 10(8), 91-100. https://doi.org/10.7176/RJFA.

Kristanto, A. A. (2012). Risiko Kebangkrutan, Proporsi Hutang dan Fenomena Underpricing pada IPO: Studi Empiris di Bursa Efek Indonesia. Jurnal Riset Manajemen Dan Bisnis, 7(1), 39-44.

Kristen, G. P., O’Connell, B., \& O’Toole, C. (2015). Do Credit Constraints Affect SME Investment and Employment? The Economic and Social Review, 46(1), 51-86.

Mukherjee, T., \& Sen, S. S. (2018). Sustainable Growth Rate and Its Determinants: A Study On Some Selected Companies in India. International Journal of Money, Banking and Finance, 6(9), 52-59.

Nasim, A., \& Irnama, F. R. (2015). Pengaruh Profit Margin, Assets Turnover dan Leverage terhadap Sustainable Growth Rate pada Perusahaan Sektor Jasa yang Terdaftar Di Bursa Efek Indonesia Periode 2010-2012. Jurnal Riset Akuntansi Dan Keuangan, 3(1), 632. https://doi.org/10.17509/jrak.v3i1.6609

Nastiti, P. K. Y., Atahau, A. D. R., \& Supramono, S. (2019). Working capital management and its influence on profitability and sustainable growth. Business: Theory and Practice, 20, 61-68. https://doi.org/10.3846/BTP.2019.06

Rahim, N. (2017). Sustainable Growth Rate and Firm Performance: a Case Study in Malaysia. International Journal of Management, Innovation \& Entrepreneurial Research, 3(2), 48-60. https://doi.org/10.18510/ijmier.2017.321

Sari, D. P. (2017). Ini Daftar Perusahaan Yang Pailit Sepanjang 2017. Kabar24.Bisnis.Com. https://kabar24.bisnis.com/read/20171228/16/721762/ini-daftar-perusahaan-yang-pailitsepanjang-2017

Setipu, Z. I. (2018). Perjalanan Sariwangi yang Pailit di 2018. Finance.Detik.Com. https://finance.detik.com/infografis/d-4264086/perjalanan-sariwangi-yang-pailit-di2018?_ga=2.85951769.1662901016.1578317159-793185487.1578317159

Sutjiati, R. (2017). Role of Sustainable Growth Rate to Increase Company's Value. International Annual $\begin{array}{llrl}\text { Symposium } & \text { on } & \text { Management, } & \text { 53(9), }\end{array}$ https://doi.org/10.1017/CB09781107415324.004 